\title{
Grafting onto pumpkin rootstock is an efficient alternative to improve melon tolerance to $\mathrm{NaCl}$ stress
}

\author{
Qiushi $\mathrm{Fu}^{1}$, Xinying Zhang ${ }^{1}$, Qiusheng Kong ${ }^{2}$, Zhilong Bie ${ }^{2}$ and Huaisong Wang ${ }^{1}$ \\ ${ }^{1}$ Institute of Vegetables and Flowers, Chinese Academy of Agricultural Sciences, Beijing, China \\ ${ }^{2}$ College of Horticulture and Forestry, Huazhong Agricultural University, Key Laboratory of Horticultural Plant Biology, \\ Ministry of Education, Wuhan, China
}

\section{Summary}

The objective of this study was to determine whether salt tolerance of Cucumis melo L. 'Baimi' could be improved by grafting onto pumpkin rootstock Cucurbita maxima Duchesne $\times$ Cucurbita moschata Duchesne 'Jingxin 3'. Both self-rooted and grafted plants were cultivated in a nutrient solution with or without $150 \mathrm{mM} \mathrm{NaCl}$. Salt treatment significantly reduced melon plant growth and productivity, leading to a series of physiological and biochemical changes. Melon plants grafted onto pumpkin rootstock showed much less inhibition of growth and photosynthesis by salt stress compared with the self-rooted plants. Stress-induced activities of superoxide dismutase, peroxidase, and catalase were considerably higher $(24.61 \%, 100.69 \%$, and $26.27 \%)$ in the rootstock-grafted plants. Leaves of these plants also had higher concentrations of total soluble sugars $(\mathbf{2 8 . 1 1 \% )}$, higher activities of sucrose synthetase $(16.77 \%)$ and sucrose phosphate synthase $(90.70 \%)$. The pumpkin rootstock significantly mitigated the negative effects of salt stress by reducing Na uptake, enhancing $\mathrm{K}$ uptake, and maintaining a higher $\mathrm{K} /$ Na ratio (19.01 for grafted plants, 8.77 for self-rooted plants) in the leaves and a lower $\mathrm{K} / \mathrm{Na}$ ratio $(0.42$ for grafted plants, 1.44 for self-rooted plants) in the roots. Quantitative RT-PCR analysis showed that transcript levels of candidate genes, CmSOS1, CmNHX1 and $C m G n T$ were significantly higher in the grafted plants than in the self-rooted plants under salt stress. These results demonstrated that the salt tolerance of melon plants could be significantly improved by using pumpkin as a rootstock.

\section{Keywords}

Cucumis melo, gene expression, physiological and biochemical responses, salt tolerance

\section{Introduction}

Salinity in the soil or water is a major abiotic stress that reduces plant growth and crop productivity worldwide. Approximately $6 \%$ of the world's total land area is affected by salt stress (Munns et al., 2012). Moreover, salinity in the surface soils of greenhouses is increased by changes in the soil water balance, which results from both a lack of leaching by rainfall as well as from excess evaporation of soil water and high rates of fertilizer application (Darwish et al., 2005). The main consequences of plant exposure to salt stress are

\section{Significance of this study}

What is already known on this subject?

- Salinity is one of the major abiotic stresses that reduce plant growth and productivity in many areas of the world. Vegetable grafting is an important agricultural technique widely used to improve plant tolerance to soil-borne diseases and abiotic stresses.

\section{What are the new findings?}

- The salt tolerance of melon plants under high salt stress level (150 mM NaCl) could be significantly improved by using pumpkin as a rootstock on the agronomical and physiological responses. Upregulated expressions of CmSOS1, CmNHX1, CmHKT1 and $\mathrm{CmGnT}$ in grafted plants indicated that these genes played a significant role in conferring salt tolerance.

What is the expected impact on horticulture?

- The use of pumpkin rootstock is a valid strategy in increasing melon salt tolerance by reducing sodium toxicity. Commercial cultivars grafting onto appropriate rootstocks could be a promising tool for growers to improve plant growth and yield under salt stress.

water deficits due to relatively high solute concentrations in the soil or excessive ions resulting from altered $\mathrm{K}^{+} / \mathrm{Na}^{+}$ratios and changes in $\mathrm{Na}^{+}$and $\mathrm{Cl}^{-}$ion concentrations (Chen et al., 2003). These adverse effects inhibit growth and can contribute to plant death (Serrano et al., 1999).

Plants employ various strategies to tolerate salinity. Excessive $\mathrm{Na}^{+}$accumulations in the symplast can be prevented via three mechanisms that function cooperatively: 1) restriction of $\mathrm{Na}^{+}$influx, 2) active $\mathrm{Na}^{+}$extrusion at the root-soil interface, and 3) vacuolar sequestration of $\mathrm{Na}^{+}$(Tester and Davenport, 2003). Transport systems that control net $\mathrm{Na}^{+}$uptake into the root xylem vessels and regulate $\mathrm{Na}^{+}$movement to the shoots are also determinants of salt tolerance (Shi et al., 2002; Munns et al., 2012). As a consequence of these primary effects, one common plant response is overproduction of different types of compatible organic solutes, e.g., soluble sugar and proline, which accumulate in many salt-stressed crops (Munns and Tester, 2008). Salt stress reduces the rate of photosynthesis, thereby limiting the supply of $\mathrm{CO}_{2}$ to the leaf. This leads to an over-reduction of the photosynthetic electron transport chain and results in the production of ROS, including superoxide, hydroxyl radicals, hydrogen per- 
oxide, and singlet oxygen, which cause significant damage to cell structures (Ashraf, 2009). Multiple antioxidant enzyme systems, in particular SOD, POD, and CAT, were believed to play an important role in ROS-scavenging, thus protecting cells from oxidative damage (Zhen et al., 2010).

The salt overly sensitive (SOS) signaling pathway has been proposed to mediate cellular signaling under salt stress, maintaining ion homeostasis and conferring salt tolerance. The $\mathrm{Na}^{+}$transporter SOS1 is a $\mathrm{Na}^{+}$-effluxing plasma membrane-located $\mathrm{Na}^{+} / \mathrm{H}^{+}$antiporter that is involved in controlling long-distance $\mathrm{Na}^{+}$transport in plants from roots to shoots. Expression of SOS1 in Arabidopsis thaliana cells indicates that this transporter has a role in controlling $\mathrm{Na}^{+}$-loading of the vascular system (Shi et al., 2002). Sequestration of excess $\mathrm{Na}^{+}$inside root or stem cell vacuoles is another strategy used by many plants to survive under salt stress (Yamaguchi et al., 2013). Plant $\mathrm{Na}^{+} / \mathrm{H}^{+}$antiporter exchanger (NHX) genes, localized in the vacuolar membrane, are involved in this compartmentalization of sodium ions into the vacuole (Apse and Blumwald, 2007). This protects essential enzymatic reactions in the cytoplasm from excess $\mathrm{Na}^{+}$levels while contributing to salt tolerance and ion homeostasis within the cells (Hasegawa et al., 2000). Some members of the high-affinity potassium transporter (HKT) protein family are thought to play major roles in $\mathrm{Na}^{+}$uptake and recirculation within salt-stressed plants (Apse and Blumwald, 2007). The HKTs are divided into two subgroups based on their transport selectivity. Those in Group 1 are $\mathrm{Na}^{+}$uniporters while proteins within Group 2 enable $\mathrm{Na}^{+}$and $\mathrm{K}^{+}$transport as well as $\mathrm{Na}^{+}$uniport at high $\mathrm{Na}^{+}$concentrations. The HKT genes from dicot species occur within the major subfamily HKT1 in Group 1 (Platten et al., 2006). N-acetylglucosaminyltransferase III (GnT-III) participates in the branching of $\mathrm{N}$-glycans, catalyzing the formation of a unique sugar chain structure-bisecting GlcNAc. This enzyme is a key glycosyltransferase in the $\mathrm{N}$-glycan biosynthetic pathway. N-acetylglucosaminyltransferase played a positive role in cellular survival in response to stress condition (Zachara et al., 2004; Zachara and Hart, 2006).

Melon (Cucumis melo L.), one of the most commercially important vegetable crops, is sensitive to soil salinity. Plant grafting is widely used to manage the probability of soilborne diseases (Crinò et al., 2007). This technique is also now applied for improving crop responses to abiotic stresses such as salinity, heavy metals, nutrient deficiencies, and alkalinity (Colla et al., 2006a, b; Rouphael et al., 2008; Colla et al., 2010; King et al., 2010; Savvas et al., 2010; Zhang et al., 2016). In the case of salt stress, grafting has been tested with Cucumis sativus L. (cucumber; Huang et al., 2013), Solanum lycopersicum L. (tomato; Di Gioia et al., 2013), Citrullus lanatus L. (watermelon; Goreta et al., 2008) and Cucumis melo L. (melon; Colla et al., 2006b). For example, when exposed to greater salinity, reductions in shoot weight and leaf area were lower for grafted watermelon than for ungrafted plants (Goreta et al., 2008). Grafting of tomato or citrus crops also decreased concentrations of $\mathrm{Na}^{+}$and $\mathrm{Cl}^{-}$in the xylem and diminished accumulations of those ions in the leaves (Fernández-García et al., 2002). Our research objective was to determine whether grafting onto a pumpkin rootstock could provide an effective way to increase salt tolerance of melon and also explore possible links between the expression levels of candidate genes (CmSOS1, CmNHX1, CmHKT1, and CmGnT) and salt tolerance in grafted melon.

\section{Materials and methods}

\section{Plant materials and growth conditions}

The experiment was conducted during the spring season of 2014 in the greenhouse at the Institute of Vegetables and Flowers, Chinese Academy of Agricultural Sciences, Beijing. As the scion, the commercial Cucumis melo L. 'Baimi' (oriental melon, obtained from the Institute of Vegetables and Flowers, Chinese Academy of Agricultural Sciences, Beijing, China) was grafted onto the commercial 'Jingxin3' pumpkin rootstock (Cucurbita maxima Duchesne $\times$ Cucurbita moschata Duchesne, obtained from Beijing Vegetable Research Center, Beijing, China). Plants were grown under natural light conditions. The green-house was maintained at daily temperatures between 17 and $33^{\circ} \mathrm{C}$, and day/night relative humidities of $55 / 85 \%$. Rootstock of pumpkin seeds were sown (on 15 April, 2014) 3 days before those of the scion ('Baimi', on 18 April) in 50 seedling plug trays filled with a $1: 1: 1(\mathrm{v} / \mathrm{v} / \mathrm{v})$ mixture of peat: vermiculite: perlite. Seven days later (from 18 April), grafting was performed using the 'insertion grafting' procedure described by Lee (1994). Ungrafted 'Baimi' was used as the control. High relative humidity $(\mathrm{RH})$ was maintained by covering the newly grafted plants with a layer of transparent plastic film and shading them for the first $72 \mathrm{~h}$. Afterward, the plastic film was opened slightly each day and removed entirely on Day 7 . Then the seedlings (with uniform growth) were transferred to 20-L plastic containers containing full strength Hoagland's solution. All nutrient solutions were prepared using deionized water. The nutrient solutions were refreshed at 5-d intervals and continuously aerated by an air pump (Huang et al., 2010; Lei et al., 2014). The $\mathrm{pH}$ of the nutrient solution was maintained close to 6.5 by adding $\mathrm{H}_{2} \mathrm{SO}_{4}$ or $\mathrm{KOH}$. At the three-true-leaf stage, grafted and control plants were subjected to the following four treatments: SC, self-rooted 'Baimi', non-stressed ( $0 \mathrm{mM} \mathrm{NaCl}$, EC $1.90 \mathrm{dSm}^{-1}$ ); SN, self-rooted 'Baimi' exposed to $150 \mathrm{mM} \mathrm{NaCl}$ (EC $15.16 \mathrm{dSm}^{-1}$ ); RC, rootstock-grafted 'Baimi', non-stressed; RN, rootstock-grafted 'Baimi' exposed to $150 \mathrm{mM} \mathrm{NaCl}$. The salt-stress experiments ran for two weeks (Huang et al., 2010), because evident growth differences were observed among the treatments. Each treatment was replicated three times, with 10 plants per replicate, in a completely randomized design.

\section{Plant growth parameters}

Plant height, stem diameter and leaf areas of 3 plants per treatment were measured after two weeks of salt treatment, then the plants were divided into leaves, stems, and roots to determine separate fresh weight (FW) values before the tissues were heated to $105^{\circ} \mathrm{C}$ for $30 \mathrm{~min}$. After oven-drying at $75^{\circ} \mathrm{C}$ for $48 \mathrm{~h}$, the tissues were re-weighed to obtain dry weight (DW) values.

\section{Photosynthetic measurements}

Five plants per replicate were selected randomly after two weeks of treatment and the third leaf from the top of each plant was used for determining photosynthesis. The net photosynthesis rate $(\mathrm{Pn})$, stomatal conductance $\left(\mathrm{g}_{\mathrm{s}}\right)$, concentration of intercellular $\mathrm{CO}_{2}\left(\mathrm{C}_{\mathrm{i}}\right)$, and transpiration rate $(\mathrm{E})$ for fully expanded leaves from fruit-bearing nodes in each treatment were measured with a portable photosynthesis system (Li-Cor 6400; Li-Cor Inc., Lincoln, NE, USA), between 9:00 am and 11:00 am. Conditions during the measurement period included constant irradiation $\left(800 \mu \mathrm{mol} \mathrm{m}^{-2} \mathrm{~s}^{-1}\right), \mathrm{a} \mathrm{CO}_{2}$ concentration in the leaf chamber of $365 \mathrm{mmol} \mathrm{mol}^{-1}$, air temperature of $25^{\circ} \mathrm{C}$, and $\mathrm{RH}$ of $70 \%$. 


\section{Evaluation of leaf pigments and antioxidant system}

The fourth leaf from the top of 6 plants per treatment were collected for pigment and antioxidant activities analysis after two weeks of treatment. Each $0.2 \mathrm{~g}$ (for leaf pigment analysis) and $0.5 \mathrm{~g}$ (for antioxidant analysis) fresh samples were collected, samples were immediately frozen in liquid nitrogen and stored at $-80^{\circ} \mathrm{C}$ for analysis. Leaf pigments in mature leaves were analyzed by extracting chlorophyll (Chl) in $80 \%$ chilled acetone $(\mathrm{v} / \mathrm{v})$ and then quantifying with a spectrophotometer (UVICON-930; Kontron Instruments, Zürich, Switzerland). In particular, Chl $a$ was determined at wavelength $663 \mathrm{~nm}, \mathrm{Chl} b$ at $646 \mathrm{~nm}$, and carotenoids at $470 \mathrm{~nm}$.

The crude enzymatic extracts from each tissue type were prepared in $0.05 \mathrm{~mol} \mathrm{~L}^{-1}$ phosphate buffer ( $\mathrm{pH} 7.8$ ) by grinding the samples with a pestle and mortar under liquid nitrogen. The homogenates were filtered through one layer of nylon and centrifuged at $12,000 \times \mathrm{g}$ for $10 \mathrm{~min}$. The supernatants were then used for assaying SOD, POD, and CAT activities. All operations were performed at $4^{\circ} \mathrm{C}$. Briefly, SOD activity was measured by the nitro blue tetrazolium method (Van Rossum et al., 1997). Activity by POD was determined as the change in absorbance of $470 \mathrm{~nm}$ due to guaiacol oxidation, based on the method described by Polle et al. (1994). For CAT, the decomposition of $\mathrm{H}_{2} \mathrm{O}_{2}$ was followed by the decline in absorbance at $240 \mathrm{~nm}$ (Cakmak and Marschner, 1992).

\section{Carbohydrate extraction and analysis}

After the photosynthetic data were collected, the first fully expanded leaves from the top of 6 plants per treatment were sampled after two weeks of treatment. Leaf samples (each $1 \mathrm{~g} \mathrm{FW}$ ) were immediately frozen in liquid nitrogen and stored at $-80^{\circ} \mathrm{C}$ for analysis. Leaf samples were finely ground and then extracted three times in $5 \mathrm{~mL}$ of $80 \%(\mathrm{v} / \mathrm{v})$ ethanol for $30 \mathrm{~min}$ at $80^{\circ} \mathrm{C}$. The extracts were combined and dried in a centrifugal evaporator. The residues were re-dissolved in $1 \mathrm{~mL}$ of distilled water and passed through a $0.45 \mu \mathrm{m}$ filter. Afterward, $10 \mu \mathrm{L}$ of each sample was injected into a high performance liquid chromatograph (HPLC) that consisted of a Sugar-Park column $(6.5 \mathrm{~mm} \times 300 \mathrm{~mm}$; Waters $)$ that operated isocratically at $75^{\circ} \mathrm{C}$ with water as an eluant $(0.5 \mathrm{~mL}$ $\mathrm{min}^{-1}$ ), plus a refractive index detector. These eluted sugars were identified and quantified based on their retention times and peak heights for sugar standards, as described by Miron and Schaffer (1991).

\section{Extraction and assays of enzymes for sugar metabolism}

After the photosynthetic data were collected, the first fully expanded leaves of 6 plants per treatment were sampled after two weeks of treatment. Fresh samples $(1 \mathrm{~g})$ of each replicate were stored in liquid nitrogen immediately for analysis. The leaf samples were finely ground in liquid nitrogen using a chilled mortar and pestle. Approximately $1 \mathrm{~g}$ of the powder was suspended in $1 \mathrm{~mL}$ of ice-cold extraction buffer containing $50 \mathrm{mM}$ HEPES-NaOH buffer ( $\mathrm{pH}$ 7.5) plus $10 \mathrm{mM} \mathrm{MgCl}_{2}, 1 \mathrm{mM}$ EDTA, $2.5 \mathrm{mM}$ DDT, 0.1\% (w/v) BSA, and $0.05 \%(\mathrm{v} / \mathrm{v})$ TritonX-100. The homogenate was centrifuged at $13,000 \times g$ for $20 \mathrm{~min}$. The resulting supernatant was dialyzed with $20 \mathrm{mM}$ HEPES-NaOH buffer ( $\mathrm{pH}$ 7.0) containing $20 \mathrm{mM}$ 2-mercaptoethanol for $16 \mathrm{~h}$. Sucrose phosphate synthase (SPS, E.C.2.4.1.14), sucrose synthase (SS, E.C.2.4.1.13), and acid and neutral invertases (AI and NI, E.C.3.2.1.26) were assayed according to the procedures of $\mathrm{Hu}$ et al. (2009).

\section{Determination of ion concentrations}

After two weeks of treatment, 6 plants per treatment were harvested and divided into leaf (first fully expanded) and root portions. After measuring their dry weights, powders $(0.5 \mathrm{~g})$ of the same type were digested in a mixture of $\mathrm{H}_{2} \mathrm{SO}_{4}-\mathrm{H}_{2} \mathrm{O}_{2}$ (volume ratio 5:1) to measure the following ion concentrations ( $\mathrm{Na}, \mathrm{P}, \mathrm{K}, \mathrm{Ca}, \mathrm{Mg}$ and $\mathrm{Fe}$ ) with atomic absorption spectrometry (Shimadzu AA-6300; Shimadzu, Tokyo, Japan).

\section{Total RNA extraction and real-time quantitative RT-PCR analysis}

Young leaf samples (about $0.2 \mathrm{~g}$ ) were collected after two weeks of treatment, frozen them immediately in liquid nitrogen and stored at $-80^{\circ} \mathrm{C}$ until use for RNA extraction. Total RNA was extracted from the leaves as described in the TRI reagent protocol (Takara Bio Inc., Japan). For all samples, the total RNA $(1 \mu \mathrm{g})$ was converted to cDNA using PrimeScript $^{\mathrm{TM}} 1^{\text {st }}$ Strand cDNA Synthesis Kits (Takara) according to the manufacturer's instructions. Primers were designed from the peptide sequences obtained after mass analysis, according to the NCBI and Melon databases (melonomics. net). Gene-specific primers used for real-time quantitative RT-PCR are shown in Table 1. All reactions were performed with SYBR PrimeScript ${ }^{\mathrm{TM}}$ RT-PCR Kits (Takara Bio Inc., Shiga, Japan) according to the manufacturer's instructions. Quantitative RT-PCR was conducted with a LightCycler ${ }^{\circledR} 96$ Instrument (Roche, Mannheim, Germany).

\section{Statistical analysis}

Data presented are the mean values of three replicates. Statistical assays were conducted via ANOVA, using the SPSS software package (SPSS 10 for Windows, 2001). Duncan's multiple range tests were then performed. For each measured variable, values were considered significantly different among treatments at $P<0.05$.

TABLE 1. Sequences of the primers used to amplify the target genes using real-time quantitative polymerase chain reactions (RT-qPCR).

\begin{tabular}{lcc}
\hline Gene & \multicolumn{1}{c}{ Forward primer } & Reverse primer \\
\hline CmNHX1 & TCTGCCTGGTGTTGAAGATAAT & GCCAATAGTAATGGACAGACG \\
CmSOS1 & TGCCCTTCAATCAGATGACAAT & TTTCTGCTTCTGTGGTGGTCTA \\
CmGnT & CCTGGGAATTGCATACGAGA & AAGACCACCACGGTTGACTG \\
CmHKT1 & TCCTCTGCCATCTTGATTCTG & TTCCCTTTCTTCTTCTTCTTCTCT \\
Actin & TCGTTCCTTCCTTCCTTCATTC & AGCCTTCACCATTCCAGTTC \\
\hline
\end{tabular}

CmNHX1 = Vacuolar membrane-located $\mathrm{Na}^{+} / \mathrm{H}^{+}$antiporter gene of melon (gene ID: 103492731).

CmSOS1 = Plasma membrane-located $\mathrm{Na}^{+} / \mathrm{H}^{+}$antiporter gene of melon (gene ID: 103504147).

$\mathrm{CmGnT}=\mathrm{N}$-Acetylglucosaminyltransferase III gene of melon (gene ID: 103488964).

CmHKT1 = High-affinity potassium transporter gene of melon (gene ID: 103494214). 
TABLE 2. Effects of NaCl treatment $(150 \mathrm{mM})$ on plant growth, photosynthesis parameters and antioxidant activities of selfrooted and rootstock-grafted melon plants.

\begin{tabular}{|c|c|c|c|c|}
\hline Parameters/Treatments & SC & SN & $\mathrm{RC}$ & $\mathrm{RN}$ \\
\hline Plant height $(\mathrm{cm})$ & $29.50 \pm 1.06 b$ & $16.00 \pm 1.20 \mathrm{~d}$ & $33.40 \pm 2.29 a$ & $21.33 \pm 1.05 c$ \\
\hline Stem diameter (mm) & $3.04 \pm 0.52 b$ & $2.80 \pm 0.16 b$ & $5.77 \pm 0.72 a$ & $5.43 \pm 0.30 \mathrm{a}$ \\
\hline Leaf area $\left(\mathrm{cm}^{2}\right)$ & $49.75 \pm 3.30 b$ & $26.61 \pm 0.93 d$ & $51.52 \pm 3.77 a$ & $35.26 \pm 2.78 c$ \\
\hline Shoot dry mass (g) & $2.86 \pm 0.12 \mathrm{a}$ & $0.47 \pm 0.01 \mathrm{c}$ & $3.05 \pm 0.15 a$ & $1.56 \pm 0.02 b$ \\
\hline Root dry mass (g) & $0.26 \pm 0.04 a$ & $0.10 \pm 0.02 c$ & $0.25 \pm 0.09 a$ & $0.16 \pm 0.01 b$ \\
\hline $\operatorname{Pn}\left(\mu \mathrm{mol} \mathrm{m} \mathrm{m}^{-2} \mathrm{~s}^{-1}\right)$ & $8.67 \pm 0.11 b$ & $3.88 \pm 0.05 d$ & $9.66 \pm 0.01 \mathrm{a}$ & $6.60 \pm 0.27 c$ \\
\hline $\mathrm{g}_{\mathrm{s}}\left(\mathrm{mol} \mathrm{H} \mathrm{H}_{2} \mathrm{Om}^{-2} \mathrm{~s}^{-1}\right)$ & $0.69 \pm 0.01 a$ & $0.11 \pm 0.01 \mathrm{c}$ & $0.61 \pm 0.01 \mathrm{a}$ & $0.26 \pm 0.00 \mathrm{~b}$ \\
\hline $\mathrm{C}_{\mathrm{i}}\left(\mu \mathrm{mol} \mathrm{mol} \mathrm{l}^{-1}\right)$ & $181.17 \pm 0.35 a$ & $141.49 \pm 1.62 c$ & $189.24 \pm 0.19 a$ & $152.73 \pm 0.69 b$ \\
\hline $\mathrm{E}\left(\mathrm{mmol} \mathrm{H} \mathrm{H}_{2} \mathrm{~m}^{-2} \mathrm{~s}^{-1}\right)$ & $6.01 \pm 0.02 a$ & $2.00 \pm 0.00 c$ & $6.26 \pm 0.01 \mathrm{a}$ & $3.89 \pm 0.02 b$ \\
\hline $\mathrm{Chl} \mathrm{a+b}\left(\mathrm{mg} \mathrm{g}^{-1}\right)$ & $2.16 \pm 0.01 a$ & $1.70 \pm 0.01 b$ & $1.78 \pm 0.01 b$ & $1.72 \pm 0.02 b$ \\
\hline $\operatorname{SOD}\left(\mathrm{U} \mathrm{g}^{-1} \mathrm{FW}\right)$ & $88.54 \pm 6.89 a$ & $68.96 \pm 5.68 c$ & $73.28 \pm 4.52 b$ & $85.93 \pm 5.87 a$ \\
\hline POD (U g $\left.{ }^{-1} \mathrm{FW} \mathrm{min}-1\right)$ & $27.22 \pm 1.25 b$ & $18.80 \pm 2.58 \mathrm{c}$ & $28.40 \pm 2.98 b$ & $37.73 \pm 4.20 \mathrm{a}$ \\
\hline CAT $\left(\mathrm{U} \mathrm{g}^{-1} \mathrm{FW} \mathrm{min}^{-1}\right)$ & $57.65 \pm 3.58 b$ & $53.94 \pm 4.23 b$ & $57.12 \pm 3.21 b$ & $68.11 \pm 4.15 a$ \\
\hline
\end{tabular}

Plant growth and the biomass data referred to the same plants. Means followed by different letters within a column indicate significant differences at $P<0.05$ by Duncan's multiple range test. Data are mean \pm SE $(n=3)$.

$\mathrm{SC}=$ self-rooted 'Baimi' exposed to $0 \mathrm{mM} \mathrm{NaCl}$; $\mathrm{SN}$ = self-rooted 'Baimi' exposed to $150 \mathrm{mM} \mathrm{NaCl}$; RC = rootstock-grafted 'Baimi' exposed to $0 \mathrm{mM}$ $\mathrm{NaCl} ; \mathrm{RN}=$ rootstock-grafted 'Baimi' exposed to $150 \mathrm{mM} \mathrm{NaCl} ; \mathrm{Pn}=$ Net photosynthetic rate; $\mathrm{g}_{\mathrm{s}}=$ stomatal conductance; $\mathrm{C}_{\mathrm{i}}=$ intercellular $\mathrm{CO}_{2}$ concentration; $\mathrm{E}=$ transpiration rate; $\mathrm{SOD}=$ superoxide dismutase; $\mathrm{POD}=$ peroxidase; $\mathrm{CAT}$ = catalase.

\section{Results}

\section{Plant growth, photosynthesis, and activities of antioxidant enzymes}

In both rootstock-grafted and self-rooted plants, values for all growth parameters decreased in response to $\mathrm{NaCl}$ treatment (Table 2). However, grafted 'Baimi' (RN) plants were significantly taller and had larger stem diameters and leaf areas when compared with the self-rooted plants (SN). Salt stress was also associated with lower shoot and root biomasses, although samples from grafted plants were less affected.

Reductions in the net photosynthesis rate $(\mathrm{Pn})$, stomatal conductance $\left(\mathrm{g}_{\mathrm{s}}\right)$, concentration of intercellular $\mathrm{CO}_{2}\left(\mathrm{C}_{\mathrm{i}}\right)$, and transpiration rate $(\mathrm{E})$ in response to $\mathrm{NaCl}$ treatment were significantly smaller for grafted plants $(31.68 \%$ for Pn, $57.38 \%$ for $g_{s}, 19.29 \%$ for $C_{i}$, and $37.86 \%$ for E) when compared with the stressed control plants (respectively decreases of $55.25 \%, 84.06 \%, 21.90 \%$, and $66.72 \%$ ). No significant differences were found in chlorophyll concentrations between grafted and self-rooted plants under salinity conditions.

Stress-induced activities of SOD, POD, and CAT in grafted leaves increased by $24.61 \%, 100.69 \%$, and $26.27 \%$ respectively when compared with the self-rooted plants (SN).

\section{Soluble sugars and enzymes}

In response to salt treatment, glucose, fructose, and stachyose concentrations decreased in both grafted and self-rooted plants while levels of sucrose and raffinose increased (Table 3). Leaves from grafted melon plants accumulated more soluble sugars, such as sucrose and glucose under salt stress. Concentrations of total soluble sugars were $28.11 \%$ higher in stressed grafted plants than in the stressed self-rooted plants (Table 3).

The induction of salt stress was associated with significant increase in SS and SPS activities, and decrease in AI and NI activities (Table 4). Compared with SN treatment, the activities of SS, SPS, AI, and NI of RN treatment increased by $16.77 \%, 90.70 \%, 47.27 \%$ and $57.48 \%$, respectively (Table 4).

\section{Concentrations of mineral elements in leaves and roots under NaCl stress}

Salinity treatments generally increased the levels of $\mathrm{Na}$ in tissue samples, with rootstock-grafted plants showing a lower concentration (decreased by $46.47 \%$ ) in the leaves but a higher concentration (increased by $115.15 \%$ ) in the roots when compared with the self-rooted control. Although exposure to $\mathrm{NaCl}$ also elevated $\mathrm{K}$ concentrations in the leaves of rootstock-grafted plants (increased by $16.03 \%$ ), roots from those plants had lower K concentrations (decreased by

TABLE 3. Effects of $\mathrm{NaCl}$ treatment $(150 \mathrm{mM})$ on soluble sugar concentrations of self-rooted and rootstock-grafted melon leaves.

\begin{tabular}{lcccc}
\hline Treatments/Sugars & SC & SN & RC & RN \\
\hline Glucose $\left(\mathrm{mg} \mathrm{g} \mathrm{g}^{-1} \mathrm{FW}\right)$ & $1.98 \pm 0.08 \mathrm{~b}$ & $0.48 \pm 0.08 \mathrm{~d}$ & $2.49 \pm 0.08 \mathrm{a}$ & $1.21 \pm 0.02 \mathrm{c}$ \\
Fructose $\left(\mathrm{mg} \mathrm{g}^{-1} \mathrm{FW}\right)$ & $0.73 \pm 0.03 \mathrm{a}$ & $0.25 \pm 0.05 \mathrm{c}$ & $0.71 \pm 0.04 \mathrm{a}$ & $0.35 \pm 0.04 \mathrm{~b}$ \\
Sucrose $\left(\mathrm{mg} \mathrm{g} \mathrm{g}^{-1} \mathrm{FW}\right)$ & $1.19 \pm 0.02 \mathrm{c}$ & $4.94 \pm 0.45 \mathrm{~b}$ & $1.28 \pm 0.08 \mathrm{c}$ & $6.15 \pm 0.15 \mathrm{a}$ \\
Raffinose $\left(\mathrm{mg} \mathrm{g} \mathrm{g}^{-1} \mathrm{FW}\right)$ & $0.32 \pm 0.03 \mathrm{~b}$ & $0.49 \pm 0.02 \mathrm{a}$ & $0.33 \pm 0.02 \mathrm{~b}$ & $0.53 \pm 0.03 \mathrm{a}$ \\
Stachyose $\left(\mathrm{mg} \mathrm{g}^{-1} \mathrm{FW}\right)$ & $1.40 \pm 0.02 \mathrm{a}$ & $0.92 \pm 0.02 \mathrm{~b}$ & $1.28 \pm 0.07 \mathrm{a}$ & $0.83 \pm 0.03 \mathrm{~b}$ \\
\hline Total soluble sugars & $5.62 \pm 0.04 \mathrm{c}$ & $7.08 \pm 0.12 \mathrm{~b}$ & $6.09 \pm 0.06 \mathrm{c}$ & $9.07 \pm 0.05 \mathrm{a}$ \\
\hline
\end{tabular}

Means followed by different letters within a column indicate significant differences at $P<0.05$ by Duncan's multiple range test. Data are mean \pm SE $(n=3)$. 
TABLE 4. Effects of $\mathrm{NaCl}$ treatment $(150 \mathrm{mM})$ on the activities of carbohydrate enzymes of self-rooted and rootstock-grafted melon leaves.

\begin{tabular}{lrrrr}
\hline Treatments/Enzymes & \multicolumn{1}{c}{$\mathrm{SC}$} & $\mathrm{SN}$ & \multicolumn{1}{c}{$\mathrm{RC}$} & $\mathrm{RN}$ \\
\hline $\mathrm{SS}\left(\mathrm{mg} \mathrm{g}^{-1} \mathrm{FW} \mathrm{h}^{-1}\right)$ & $1.50 \pm 0.42 \mathrm{c}$ & $6.38 \pm 1.05 \mathrm{~b}$ & $1.45 \pm 0.23 \mathrm{c}$ & $7.45 \pm 0.98 \mathrm{a}$ \\
$\mathrm{SPS}\left(\mathrm{mg} \mathrm{g}^{-1} \mathrm{FW} \mathrm{h}^{-1}\right)$ & $1.46 \pm 0.28 \mathrm{c}$ & $2.15 \pm 0.25 \mathrm{~b}$ & $2.38 \pm 0.54 \mathrm{~b}$ & $4.10 \pm 0.51 \mathrm{a}$ \\
$\mathrm{Al}\left(\mathrm{mg} \mathrm{g}^{-1} \mathrm{FW} \mathrm{h}{ }^{-1}\right)$ & $32.17 \pm 3.27 \mathrm{c}$ & $24.50 \pm 4.80 \mathrm{~d}$ & $39.17 \pm 3.06 \mathrm{a}$ & $36.08 \pm 1.32 \mathrm{~b}$ \\
$\mathrm{NI}\left(\mathrm{mg} \mathrm{g}^{-1} \mathrm{FW} \mathrm{h}^{-1}\right)$ & $11.61 \pm 0.57 \mathrm{~b}$ & $7.22 \pm 0.38 \mathrm{c}$ & $15.36 \pm 1.69 \mathrm{a}$ & $11.37 \pm 2.78 \mathrm{~b}$ \\
\hline
\end{tabular}

Means followed by different letters within a column indicate significant differences at $P<0.05$ by Duncan's multiple range test. Data are mean $\pm S E$ $(n=3)$. SS = sucrose synthetase; SPS = sucrose phosphate synthase; $\mathrm{Al}=$ acid invertase; $\mathrm{NI}=$ neutral invertase.

TABLE 5. Effects of $\mathrm{NaCl}$ treatment $(150 \mathrm{mM})$ on the concentrations of mineral elements ( $\mathrm{Na}, \mathrm{K}, \mathrm{P}, \mathrm{Ca}, \mathrm{Mg}$, Fe) of self-rooted and rootstock-grafted melon leaves.

\begin{tabular}{|c|c|c|c|c|c|c|c|c|}
\hline \multirow{2}{*}{ Mineral } & \multicolumn{4}{|c|}{ Leaf $\left(\mathrm{mg} \mathrm{g}^{-1} \mathrm{DW}\right)$} & \multicolumn{4}{|c|}{ Root (mg g $\left.{ }^{-1} \mathrm{DW}\right)$} \\
\hline & SC & SN & $\mathrm{RC}$ & $\mathrm{RN}$ & SC & SN & $\mathrm{RC}$ & $\mathrm{RN}$ \\
\hline $\mathrm{Na}$ & $1.42 \pm 0.02 b$ & $3.40 \pm 0.23 a$ & $0.99 \pm 0.06 c$ & $1.82 \pm 0.17 b$ & $5.48 \pm 0.94 d$ & $16.37 \pm 0.94 b$ & $10.65 \pm 1.31 \mathrm{c}$ & $35.22 \pm 1.67 a$ \\
\hline K & $25.21 \pm 2.97 \mathrm{c}$ & $29.81 \pm 0.10 \mathrm{~b}$ & $28.51 \pm 0.39 b$ & $34.59 \pm 3.82 a$ & $28.80 \pm 3.89 a$ & $23.51 \pm 1.70 \mathrm{~b}$ & $19.22 \pm 2.38 c$ & $14.68 \pm 2.25 d$ \\
\hline$P$ & $3.10 \pm 0.53 b c$ & $3.67 \pm 0.86 b$ & $2.86 \pm 0.38 \mathrm{c}$ & $4.97 \pm 0.13 a$ & $3.82 \pm 0.21 \mathrm{c}$ & $5.34 \pm 0.41 b$ & $4.14 \pm 0.24 c$ & $6.54 \pm 0.57 a$ \\
\hline $\mathrm{Ca}$ & $30.85 \pm 3.10 \mathrm{a}$ & $23.30 \pm 3.08 \mathrm{c}$ & $31.36 \pm 2.66 a$ & $26.42 \pm 2.23 b$ & $12.89 \pm 2.84 b$ & $10.80 \pm 2.31 \mathrm{c}$ & $14.32 \pm 2.18 \mathrm{a}$ & $12.23 \pm 1.67 b$ \\
\hline $\mathrm{Mg}$ & $7.56 \pm 1.00 \mathrm{~b}$ & $6.83 \pm 0.83 b$ & $8.86 \pm 2.02 a$ & $7.56 \pm 0.30 \mathrm{~b}$ & $5.05 \pm 1.07 b$ & $3.76 \pm 0.43 c$ & $6.26 \pm 0.84 a$ & $4.92 \pm 0.73 b$ \\
\hline $\mathrm{Fe}$ & $1.41 \pm 0.27 a$ & $0.77 \pm 0.10 \mathrm{~b}$ & $1.16 \pm 0.50 \mathrm{a}$ & $0.93 \pm 0.11 b$ & $6.96 \pm 1.60 \mathrm{~b}$ & $3.39 \pm 0.72 d$ & $8.53 \pm 3.19 a$ & $5.00 \pm 0.80 c$ \\
\hline
\end{tabular}

Means followed by different letters within a line (respectively in leaf and root) indicate significant differences at $P<0.05$ by Duncan's multiple range test. Data are mean \pm SE $(n=3)$.

$37.56 \%$ ) than roots from the self-rooted control (Table 5). The pumpkin rootstock had a significant influence on P concentrations in stressed plants, with values being higher in their leaves and roots than in tissues from self-rooted plants. Similarly, Ca levels were higher in both the leaves and roots of rootstock-grafted plants than in corresponding samples from the self-rooted plants. Finally, concentrations of $\mathrm{Mg}$ and Fe in roots were significantly affected by the pumpkin rootstock, being 30.85\% higher for $\mathrm{Mg}$ and $47.49 \%$ higher for Fe when compared with the self-rooted control, whereas no significant differences among treatments were observed on $\mathrm{Mg}$ and Fe concentrations in leaves.

\section{Expression of candidate genes for salt tolerance}

Quantitative RT-PCR analysis showed that transcripts of candidates CmSOS1, CmNHX1, CmHKT1 and CmGnTIII were more abundant in stressed rootstock-grafted tissues than in their unstressed counterparts (Figure 1). Under salinity conditions, expressions of CmSOS1, CmNHX1, and CmGnT in leaves from grafted plants were 2.1-fold, 2.2-fold and 2.1fold higher, respectively, than in leaves from the self-rooted plants.

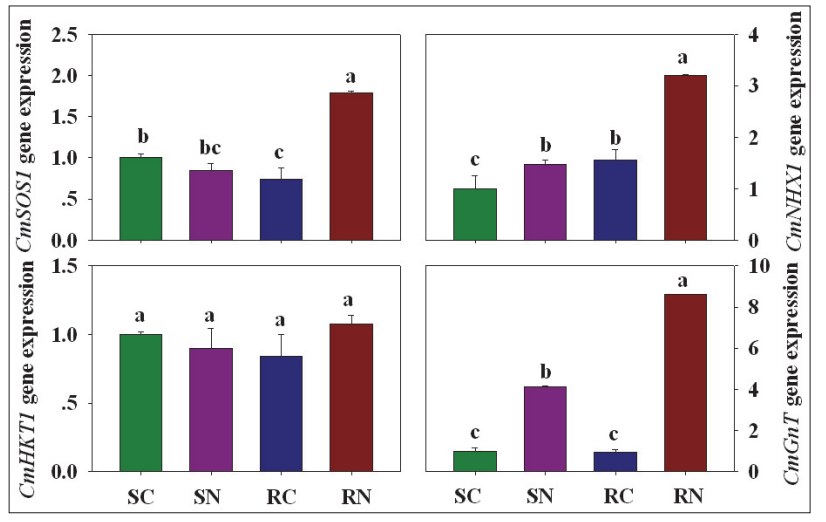

\section{Discussion}

Growth can be inhibited by salinity because stressed plants often show a decrease in their photosynthetic capacity. High salt concentrations strongly limit $\mathrm{CO}_{2}$ fixation, as reflected in net photosynthesis rates, stomatal conductance, and intercellular $\mathrm{CO}_{2}$ concentrations (Rouphael et al., 2012). At a treatment level of $150 \mathrm{mM} \mathrm{NaCl}$, rootstock-grafted plants showed higher values for $\mathrm{Pn}, \mathrm{g}_{\mathrm{s}}, \mathrm{Ci}$ and $\mathrm{E}$, which clearly demonstrated that this practice moderated the effects of salt stress for this crop. The pumpkin rootstock can directly influence growth and photosynthesis through interactions among the following processes: increases in the uptake of water and nutrients due to a more vigorous root system (Lee, 1994), enhanced production of endogenous hormones (Zijlstra et al., 1994), or improvements in scion vigor (Colla et al., 2006a, b). Similar results have been reported on Citrus spp. and Prunus spp. (Massai et al., 2004), and Cucumis sativus and Cucumis melo (Rouphael et al., 2012) when elite cultivars were grafted onto salt-tolerant rootstocks.

The development of salt tolerance in plants requires a net increase in the quantity of osmotically active solutes in tissues (Huang et al., 2010). Soluble sugars serve as osmotic

FiguRE 1. Analysis of relative expression for putative CmSOS1, CmNHX1, CmHKT1 and CmGnT by qRT-PCR in leaves from self-rooted and rootstock-grafted plants. Tissues were sampled after plants were exposed to $150 \mathrm{mM} \mathrm{NaCl}$ for two weeks. For each gene, expression was normalized to the level measured in plants of SC, for which it was assigned a value of ' 1 '. The data for each variable were analyzed by ANOVA first and then followed by Duncan's multiple range test at $\mathrm{P}<0.05$. Data are mean $\pm \mathrm{SE}(n=3)$. SC $=$ self-rooted 'Baimi' exposed to $0 \mathrm{mM} \mathrm{NaCl}$; $\mathrm{SN}$ = self-rooted 'Baimi' exposed to $150 \mathrm{mM} \mathrm{NaCl}$; RC = rootstock-grafted 'Baimi' exposed to $0 \mathrm{mM} \mathrm{NaCl}$; $\mathrm{RN}=$ rootstock-grafted 'Baimi' exposed to $150 \mathrm{mM} \mathrm{NaCl}$. 
regulators. Thus, a salinity-related rise in sugar concentrations in leaves from our grafted melon probably reflected an osmotic adjustment that was achieved through the enhanced synthesis of sugars. The pumpkin rootstock also significantly mitigated the negative effects of salt stress by reducing $\mathrm{Na}$ uptake, enhancing $\mathrm{K}$ uptake, and maintaining a higher $\mathrm{K} /$ $\mathrm{Na}$ ratio in the leaves and a lower $\mathrm{K} / \mathrm{Na}$ ratio in the roots. The maintenance of $\mathrm{K}$ selectivity could be a strategy used by grafted plants for increasing their salt tolerance (Cayuela et al., 2001; Chen et al., 2003; Kaya et al., 2003; Estañ et al., 2005; Martinez-Rodriguez et al., 2008).

To explore the differential response to salt stress between self-rooted and grafted plants, we measured the expression of key genes SOS1, NHX1, HKT1, and GnT. Exposure to $150 \mathrm{mM} \mathrm{NaCl}$ induced the up-regulation of putative SOS1 and NHX1 expression in our grafted plants. SOS1 had a critical role in controlling $\mathrm{Na}^{+}$compartmentalization by mediating vacuolar integrity and $\mathrm{pH}$ homeostasis under salt stress (Zhu, 2002). The NHX1 protein was localized in the vacuolar membrane and protected cells against the effects of salinity by sequestering toxic concentrations of sodium ion into the vacuole (Serrano et al., 1999). Nawaz et al. (2014) compared six Brassicaceae glycophytes and halophytes for salt tolerance and the expression levels of the candidate salt tolerance genes, high-level salt tolerance was associated with a strongly enhanced expression of the $\mathrm{Na}^{+}$transporters, $N H X 1$ and SOS1. Similar salt tolerance has been seen in cucumber (Lei et al., 2014), tomato (Zhang and Blumwald, 2001), and rice (Fukuda et al., 2004).

HKT1 modulated $\mathrm{Na}^{+}$influx into cells and was a key factor in determining salinity tolerance because it was involved in regulating the distribution of $\mathrm{Na}^{+}$between roots and shoots by helping to retrieve $\mathrm{Na}^{+}$from the transpiration stream (Sunarpi et al., 2005). Seven functional OsHKT genes were found to exist in a japonica rice (Oryza sativa) cultivar and similar composition of the HKT gene family was observed in wheat and barley (Hamamoto et al., 2015). Initial studies in the model plant Arabidopsis thaliana identified the AtHKT1;1 transporter as a largely $\mathrm{Na}^{+}$selective transporter and found that the AtHKT1;1 gene provided a key mechanism for protecting leaves from $\mathrm{Na}^{+}$over accumulation under salt stress (Rus et al., 2004; Sunarpi et al., 2005). Assaha et al. (2015) reported that salinity-induced expression of HKT may be crucial for $\mathrm{Na}^{+}$exclusion in the leaf of huckleberry (Solanum scabrum Mill.), on the contrary, SmHKT was repressed in the leaf of eggplant (Solanum melongena L.) under salt stress. In our study, the expression of $C m H K T 1$ gene was a little higher in grafted melon leaves under salt stress; however, no significant differences were observed between self-rooted and grafted melon under salt stress.

Glycosyltransferases have critical roles in maintaining cell homeostasis, and in regulating plant growth and development. For example, the Arabidopsis glycosyltransferase gene UGT85A5 was significantly induced by salt stress, indicating that it was involved in conferring salt tolerance. When this gene was over-expressed in Nicotiana tabacum, seeds from transgenic plants had higher germination rates, and salt-stressed seedlings exhibited better growth, decreased losses of chlorophyll, and more proline and soluble sugars (Wang et al., 2012; Sun et al., 2013). So, improved expressions by CmSOS1, CmNHX1, and CmGnT were necessary to the higher degree of salt tolerance by grafted melon.

\section{Conclusions}

Salinity significantly reduced plant growth and crop productivity, leading to a series of physiological and biochemical changes. Melon plants grafted onto pumpkin rootstock maintained higher biomass production exposed to excess $\mathrm{NaCl}$, greater capacity for photosynthesis, stronger ability to remove oxide products, and better nutritional status. Higher $\mathrm{Na}$ concentrations in the roots of grafted plants meant that less of that ion was allocated to the shoots. Up-regulated expressions of $C m N H X 1, C m S O S 1$, and $C m G n T$ in grafted plants indicated that these genes played a significant role in conferring salt tolerance. The salt tolerance of melon plants could be significantly improved by using pumpkin as a rootstock.

\section{Acknowledgments}

We are grateful for the support provided by the National Natural Science Foundation of China (31201642 and 31471895) and the China Agriculture Research System of Watermelon and Melon (CARS-25). This work is also funded by the Innovation Engineering Project of the Chinese Academy of Agricultural Sciences.

\section{References}

Apse, M.P., and Blumwald, E. (2007). Na ${ }^{+}$transport in plants. FEBS Lett. 581, 2247-2254. https://doi.org/10.1016/j.febslet.2007.04.014.

Ashraf, M. (2009). Biotechnological approach of improving plant salt tolerance using antioxidants as markers. Biotechnol. Adv. 27, 84-93. https://doi.org/10.1016/j.biotechadv.2008.09.003.

Assaha, D.V.M., Mekawy, A.M.M., Ueda, A., and Saneoka, H. (2015). Salinity-induced expression of $H K T$ may be crucial for $\mathrm{Na}^{+}$exclusion in the leaf blade of huckleberry (Solanum scabrum Mill.), but not of eggplant (Solanum melongena L.). Biochem. Bioph. Res. Co. 460, 416-421. https://doi.org/10.1016/j.bbrc.2015.03.048.

Cakmak, I., and Marschner, H. (1992). Magnesium deficiency and high light intensity enhance activities of superoxide dismutase, ascorbate peroxidase, and glutathione reductase in bean leaves. Plant Physiol. 98, 1222-1227. https://doi.org/10.1104/pp.98.4.1222.

Cayuela, E., Estañ, M.T., Parra, M., Caro, M., and Bolarin, M.C. (2001). $\mathrm{NaCl}$ pre-treatment at the seedling stage enhances fruit yield of tomato plants irrigated with salt water. Plant Soil 230, 231-238. https://doi.org/10.1023/A:1010380432447.

Chen, G., Fu, X., Lips, S.H., and Sagi, M. (2003). Control of plant growth resides in the shoot, and not in the root, in reciprocal grafts of flacca and wild-type tomato (Lycopersicon esculentum), in the presence and absence of salinity stress. Plant Soil 256, 205-215. https://doi. org/10.1023/A:1026279719242.

Colla, G., Rouphael, Y., Cardarelli, M., and Rea, E. (2006a). Effect of salinity on yield, fruit quality, leaf gas exchange, and mineral composition of grafted watermelon plants. HortScience 41, 622-627.

Colla, G., Rouphael, Y., Cardarelli, M., Massa, D., Salerno, A., and Rea, E. (2006b). Yield, fruit quality and mineral composition of grafted melon plants grown under saline conditions. J. Hortic. Sci. Biotechnol. 81, 146-152. https://doi.org/10.1080/14620316.2006.11512041.

Colla, G., Rouphael, Y., Leonardi, C., and Bie, Z.L. (2010). Role of grafting in vegetable crops grown under saline conditions. Sci. Hortic. 127, 147-155. https://doi.org/10.1016/j.scienta.2010.08.004.

Crinò, P., Lo Bianco, C., Colla, G., Rouphael, Y., and Saccardo, F. (2007). Evaluation of rootstock resistance to fusarium wilt and gummy stem blight and effect on yield and quality of a grafted 'Inodorus' melon. HortScience 42, 521-525. 
Darwish, T., Atallah, T., Moujabber, M.E., and Khatib, N. (2005). Salinity evolution and crop response to secondary soil salinity in two agro-climatic zones in Lebanon. Agr. Water Mgt. 78, 152-164. https://doi.org/10.1016/j.agwat.2005.04.020.

Di Gioia, F., Signore, A., Serio, F., and Santamaria, P. (2013). Grafting improves tomato salinity tolerance through sodium partitioning within the shoot. HortScience 48, 855-862.

Estañ, M.T., Martinez-Rodriguez, M.M., Perez-Alfocea, F., Flowers, T.J., and Bolarin, M.C. (2005). Grafting raises the salt tolerance of tomato through limiting the transport of sodium and chloride to the shoot. J. Exp. Bot. 56, 703-712. https://doi.org/10.1093/jxb/eri027.

Fernández-García, N., Martinez, V., Cerda, A., and Carvajal, M. (2002). Water and nutrient uptake of grafted tomato plants grown under saline conditions. J. Plant Physiol. 159, 899-905. https://doi. org/10.1078/0176-1617-00652.

Fukuda, A., Nakamura, A., Tagir, A., Tanaka, H., Miyao, A., Hirochika, H., and Tanaka, Y. (2004). Function, intracellular localization and the importance in salt tolerance of a vacuolar $\mathrm{Na}^{+} / \mathrm{H}^{+}$antiporter from rice. Plant Cell Physiol. 45, 146-159. https://doi.org/10.1093/pcp/ pch014.

Goreta, S., Bucevic-Popovic, V., Selak, G.V., Pavela-Vrancic, M., and Perica, S. (2008). Vegetative growth, superoxide dismutase activity and ion concentration of salt-stressed watermelon as influenced by rootstock. J. Agr. Sci. 146, 695-704. https://doi.org/10.1017/ S0021859608007855.

Hamamoto, S., Horie, T., Hauser, F., Deinlein, U., Schroeder, J.I., and Uozumi, N. (2015). HKT transporters mediate salt stress resistance in plants: from structure and function to the field. Curr. Opin. Biotech. 32,113-120. https://doi.org/10.1016/j.copbio.2014.11.025.

Hasegawa, P.M., Bressan, P.A., Zhu, J., and Bohnert, H.J. (2000). Plant cellular and molecular responses to high salinity. Annu. Rev. Plant Physiol. Plant Mol. Biol. 51, 463-499. https://doi.org/10.1146/ annurev.arplant.51.1.463.

Hu, L.P., Meng, F.Z., Wang, S.H., Sui, X.L., Li, W., Wei, Y.X., Sun, J.L., and Zhang, Z.X. (2009). Changes in carbohydrate levels and their metabolic enzymes in leaves, phloem sap and mesocarp during cucumber (Cucumis sativus L.) fruit development. Sci. Hortic. 121, 131-137. https://doi.org/10.1016/j.scienta.2009.01.023.

Huang, Y., Bie, Z.L., He, S.P., Hua, B., Zhen, A., and Liu, Z.X. (2010). Improving cucumber tolerance to major nutrients induced salinity by grafting onto Cucurbita ficifolia. Environ. Exp. Bot 69, 32-38. https://doi.org/10.1212/01.WNL.0000160395.43761.AC.

Huang, Y., Bie, Z.L., Liu, P.Y., Niu, M.L., Zhen, A., Liu, Z.X., Lei, B., Gu, D.J., Lu, C., and Wang, B.T. (2013). Reciprocal grafting between cucumber and pumpkin demonstrates the roles of the rootstock in the determination of cucumber salt tolerance and sodium accumulation. Sci. Hortic. 149, 47-54. https://doi.org/10.1016/j. scienta.2012.04.018.

Kaya, C., Higgs, D., Kirnak, H., and Tas, I. (2003). Ameliorative effects of calcium nitrate on cucumber and melon plants drip irrigated with saline water. J. Plant Nutr. 26, 1665-1681. https://doi.org/10.1081/ PLN-120022379.

King, S.R., Davis, A.R., Zhang, X., and Crosby, K. (2010). Genetic, breeding and selection of rootstocks for Solanaceae and Cucurbitaceae. Sci. Hortic. 127, 106-111. https://doi.org/10.1016/j. scienta.2010.08.001.

Lee, J.M. (1994). Cultivation of grafted vegetables, I: Current status, grafting methods, and benefits. HortScience 29, 235-239.

Lei, B., Huang, Y., Xie, J.J., Liu, Z.X., Zhen, A., Fan, M.L., and Bie, Z.L. (2014). Increased cucumber salt tolerance by grafting on pumpkin rootstock and after application of calcium. Biol. Plant. 58, 179-184. https://doi.org/10.1007/s10535-013-0349-6.
Martinez-Rodriguez, M.M., Estañ, M.T., Moyano, E., Garcia-Abellan, J.O., Flores, F.B., Campos, J.F., Al-Azzawi, M.J., Flowers, T.J., and Bolarin, M.C. (2008). The effectiveness of grafting to improve salt tolerance in tomato when an 'excluder' genotype is used as scion. Environ. Exp. Bot. 63, 392-401. https://doi.org/10.1016/j. envexpbot.2007.12.007.

Massai, R., Remorini, D., and Tattni, M. (2004). Gas exchange, water relations and osmotic adjustment in two scion/ rootstock combinations of Prunus under various salinity concentrations. Plant Soil 259, 153-162. https://doi.org/10.1023/ B:PLS0.0000020954.71828.13.

Miron, D., and Schaffer, A.A. (1991). Sucrose phosphate synthase, sucrose synthase and invertase activity in developing fruit of Lycopersicon esculentum Mill. and the sucrose-accumulating Lycopersicon hirsutum Humb. and Bonpl. Plant Physiol. 95, 623-627. https://doi.org/10.1104/pp.95.2.623.

Munns, R., and Tester, M. (2008). Mechanisms of salinity tolerance. Annu. Rev. Plant Biol. 59, 651-681. https://doi.org/10.1146/ annurev.arplant.59.032607.092911.

Munns, R., James, R.A., Xu, B., Athman, A., Conn, S.J., Jordans, C., Byrt, C.S., Hare, R.A., Tyerman, S.D., Tester, M., Plett, D., and Gilliham, M. (2012). Wheat grain yield on saline soils is improved by an ancestral $\mathrm{Na}^{+}$transporter gene. Nat. Biotechnol. 30, 360-364. https://doi. org/10.1038/nbt.2120.

Nawaz, I., Iqbal, M., Hakvoort, H.W.J., Bliek, M., de Boer, B., and Schat, H. (2014). Expression levels and promoter activities of candidate salt tolerance genes in halophytic and glycophytic Brassicaceae. Environ. Exp. Bot. 99, 59-66. https://doi.org/10.1016/j. envexpbot.2013.10.006.

Platten, J.D., Cotsaftis, O., Berthomieu, P., Bohnert, H., Davenport R.J., Fairbairn, D.J., Horie, T., Leigh, R.A., Lin, H.X., Luan, S., Mäser, P., Pantoja, O., Rodríguez-Navarro, A., Schachtman, D.P., Schroeder, J.I Sentenac, H., Uozumi, N., Véry, A.A., Zhu, J.K., Dennis, E.S., and Tester, M. (2006). Nomenclature for HKT transporters, key determinants of plant salinity tolerance. Trends Plant Sci. 11, 372-374. https://doi. org/10.1016/j.tplants.2006.06.001.

Polle, A., Otter, T., and Seifert, F. (1994). Apoplastic peroxidases and lignification in needles of Norway spruce. Plant Physiol. 106, 53-60. https://doi.org/10.1104/pp.106.1.53.

Rouphael, Y., Cardarelli, M., Colla, G., and Rea, E. (2008). Yield mineral composition, water relations, and water use efficiency of grafted mini-watermelon plants under deficit irrigation. HortScience 43, $730-736$

Rouphael, Y., Cardarelli, M., Rea, E., and Colla, G. (2012). Improving melon and cucumber photosynthetic activity, mineral composition, and growth performance under salinity stress by grafting onto Cucurbita hybrid rootstocks. Photosynthetica 50, 180-188. https:// doi.org/10.1007/s11099-012-0002-1.

Rus, A., Lee, B.H., Muñoz-Mayor, A., Sharkhuu, A., Miura, K., Zhu, J.K., Bressan, R.A., and Hasegawa, P.M. (2004). AtHKT1 facilitates $\mathrm{Na}^{+}$ homeostasis and $\mathrm{K}^{+}$nutrition in planta. Plant Physiol. 136, 25002511. https://doi.org/10.1104/pp.104.042234.

Savvas, D., Colla, G., Rouphael, Y., and Schwarz, D. (2010). Amelioration of heavy metal and nutrient stress in fruit vegetables by grafting. Sci. Hortic. 127, 156-161. https://doi.org/10.1016/j. scienta.2010.09.011

Serrano, R., Mulet, J.M., Rios, G., Marquez, J.A., de Larriona, I.F., Leube, M.P., Mendizabal, I., Pascual-Ahuir, A., Proft, M., Ros, R. and Montesinos, C. (1999). A glimpse of the mechanisms of ion homeostasis during stress. J. Exp. Bot. 50, 1023-1036. https://doi. org/10.1093/jxb/50.Special_Issue.1023. 
Shi, H.Z., Quintero, F.J., Pardo, J.M., and Zhu, J.K. (2002). The putative plasma membrane $\mathrm{Na}^{+} / \mathrm{H}^{+}$antiporter SOS1 controls long-distance $\mathrm{Na}^{+}$transport in plants. Plant Cell 14, 465-477. https://doi. org/10.1105/tpc.010371.

Sun, Y.G., Wang, B., Jin, S.H., Qu, X.X., Li, Y.J., and Hou, B.K. (2013). Ectopic expression of Arabidopsis glycosyltransferase UGT85A5 enhances salt stress tolerance in tobacco. PLoS One 8, e59924. https://doi.org/10.1371/journal.pone.0059924.

Sunarpi, Horie, T., Motoda, J., Kubo, M., Yang, H., Yoda, K., Horie, R., Chan, W.Y., Leung, H.Y., Hattori, K., Konomi, M., Osumi, M., Yamagami, M., Schroeder, J.I., and Uozumil, N. (2005). Enhanced salt tolerance mediated by AtHKT1 transporter-induced $\mathrm{Na}^{+}$unloading from xylem vessels to xylem parenchyma cells. Plant J. 44, 928-938. https://doi. org/10.1111/j.1365-313X.2005.02595.x.

Tester, M., and Davenport, R. (2003). $\mathrm{Na}^{+}$transport and $\mathrm{Na}^{+}$tolerance in higher plants. Ann. Bot. 91, 503-527. https://doi.org/10.1093/ $\mathrm{aob} / \mathrm{mcg} 058$.

Van Rossum, M.W.P.C., Alberda, M., and Van der Plas, L.H.W. (1997). Role of oxidative damage in tulip bulb scale micropropagation. Plant Sci. 130, 207-216. https://doi.org/10.1016/S0168-9452(97) 00215-X.

Wang, B., Jin, S.H., Hu, H.Q., Sun, Y.G., Wang, Y.W., Han, P., and Hou, B.K. (2012). UGT87A2, an Arabidopsis glycosyltransferase gene, regulates flowering time via FLOWERING LOCUS C. New Phytol. 194, 666-675. https://doi.org/10.1111/j.1469-8137.2012.04107.x.

Yamaguchi, T., Hamamoto, S., and Uozumi, N. (2013). Sodium transport system in plant cells. Front. Plant Sci. 4, 410. https://doi. org/10.3389/fpls.2013.00410.

Zachara, N.E., and Hart, G.W. (2006). Cell signaling, the essential role of 0-GlcNAc! Biochim. Biophys. Acta 1761, 599-617. https://doi. org/10.1016/j.bbalip.2006.04.007.

Zachara, N.E., O'Donnell, N., Mercer, J.J., Marth, J.D., and Hart, G.W. (2004). Dynamic 0-GlcNAc modification of nucleocytoplasmic proteins in response to stress. J. Biol. Chem. 279, 30133-30142. https://doi.org/10.1074/jbc.M403773200.

Zhang, H.X., and Blumwald, E. (2001). Transgenic salt-tolerant tomato plants accumulate salt in foliage but not in fruit. Nat. Biotechnol. 19, 765-768. https://doi.org/10.1038/90824.

Zhang, L., Marguerit, E., Rossdeutsch, L., Ollat, N., and Gambetta, G.A. (2016). The influence of grapevine rootstocks on scion growth and drought resistance. Theor. Exp. Plant Physiol. 28, 143-157. https:// doi.org/10.1007/s40626-016-0070-x.

Zhen, A., Bie, Z.L., Huang, Y., Liu, Z.X., and Li, Q. (2010). Effects of scion and rootstock genotypes on the anti-oxidant defense systems of grafted cucumber seedlings under $\mathrm{NaCl}$ stress. J. Soil Sci. Plant Nutr. 56(2), 263-271.

Received: Jul. 25, 2017

Accepted: Dec. 8, 2017

Addresses of authors:

Qiushi $\mathrm{Fu}^{1}$, Xinying Zhang ${ }^{1}$, Qiusheng Kong ${ }^{2}$, Zhilong Bie ${ }^{2}$ and Huaisong Wang ${ }^{1, *}$

${ }^{1}$ Institute of Vegetables and Flowers, Chinese Academy of Agricultural Sciences, Beijing 100081, China

${ }^{2}$ College of Horticulture and Forestry, Huazhong Agricultural University, Key Laboratory of Horticultural Plant Biology,

Ministry of Education, Wuhan 430070, China

* Corresponding author;

E-mail: wanghuaisong06@sina.com

Tel. and fax: +861082105984 